\title{
Experimental Trypanosoma evansi infection in donkeys: hematological, biochemical and histopathological changes
}

[Infecção experimental em jumentos com Trypanosoma evansi: alterações hematológicas, bioquímicas e histopatológicas]

\author{
F.A. Cadioli, L.C. Marques ${ }^{*}$, R.Z. Machado, A.C. Alessi, L.P.C.T. Aquino, P A. Barnabé \\ Faculdade de Ciências Agrárias e Veterinárias - Unesp \\ Via de Acesso Prof. Paulo Donato Castellane, s/n \\ 14884-900 - Jaboticabal, SP
}

\begin{abstract}
Five adult donkeys were experimentally infected with Brazilian strain of Trypanosoma evansi originally isolated from a naturally infected dog to study the hematological biochemical and histopathological alterations during the evolution of the disease. The course of the experimental infection was followed up to 145 days. Hematological analyses of the infected donkeys revealed a marked decline in hemoglobin, packed-cell volume, and erythrocyte count. Anemia was observed after successive peaks of parasitemia. Biochemical analyses showed increased levels of icterus index, serum globulins and decreased serum albumin and glucose values. All infected donkeys revealed enlargement of spleen and its white pulp, enlargement of mediastinal lymph nodes and lungs congestion. The main histopathological features consisted of meningoencephalitis. Demyelination in some areas of the cerebellum pediculus and neuropil vacuolization were observed. This study showed that donkeys infected with a Brazilian strain of T. evansi developed a chronic disease.
\end{abstract}

Keywords: donkey, experimental infection, Trypanosoma evansi, trypanosomiasis

\section{RESUMO}

Cinco jumentos, adultos foram infectados experimentalmente com cepa brasileira de Trypanosoma evansi, isolada de um cão naturalmente infectado, com o intuito de observar as alterações hematológicas, bioquímicas e histopatológicas durante a evolução da enfermidade. O curso da infecção experimental foi de 145 dias. Análise hematológica dos jumentos infectados revelou declínio nos valores de hemoglobina, hematócrito e contagem total de eritrócitos. Notou-se anemia após sucessivos picos de parasitemia. Análise bioquímica indicou aumento dos niveis de indice ictérico, globulinas séricas e diminuição dos valores séricos de albumina e glicose. Todos os jumentos infectados apresentaram aumento do baço e de sua polpa branca, aumento de linfonodos mediastínicos e congestão pulmonar. Meningoencefalite foi o principal achado histopatológico. Em algumas áreas do pedículo cerebelar foram observadas desmielinização, além de vacuolização do neurópilo. O estudo mostrou que jumentos infectados com a cepa brasileira do T. evansi desenvolveram doença crônica.

Palavras-chave: jumento, infecção experimental, Trypanosoma evansi, tripanosomíase

Recebido em 18 de abril de 2005

Aceito em 22 de novembro de 2005

*Corresponding author (autor para correspondência)

E-mail: 1marques@fcav.unesp.br

Apoio: FAPESP (98/15161-8) 


\section{INTRODUCTION}

Serious outbreaks of equine trypanosomiasis occur in the Brazilian Pantanal, where of cattle and horses are bred on large farms (Silva et al., 1995). In this area, trypanosomiasis due to Trypanosoma evansi is enzootic since it affects many species of domestic and wild animals (Franke et al., 1994; Herrera et al., 2002). The course of the disease lasts between one week to six months (Woo, 1977) and usually results in emaciation and death. The pre-patent period varies from 4 to 13 days and parasitemia displays an undulanting course (Ramirez et al., 1979).

Anemia is a commonly found in horses, donkeys, dogs and coatis (Nasua nasua) experimentally infected with T. evansi (Marques et al., 2000; Soodan et al., 1996; Aquino et al, 2002; Herrera et al., 2002). Some alterations in blood biochemistry, including decrease in blood albumin and increase in globulin levels, hypoglycemia and increase in icterus index, have been reported in donkeys and horses (Soodan et al., 1996; Marques et al., 2000). Pathological changes detected in experimentally infected donkeys include enlarged spleen with hypertrophy of lymphoid follicles, congested lungs and neuronal degeneration and meningoencephalitis (Soodan et al., 1996).

Despite the importance and the worldwide distribution of $T$. evansi, very little is known about its pathogenesis. Moreover, there are no studies about this disease in donkeys with the Brazilian strains of this parasite. This study aimed to investigate some hematological, biochemical and histopathological alterations in donkeys experimentally infected with $T$. evansi.

\section{MATERIALS AND METHODS}

Five healthy donkeys, three males and two females, aged 4-to-6 years, from farms free of $T$. evansi, were used. All donkeys were dewormed ${ }^{1}$ upon arrival and maintained in a flyproof isolation unit during all the experiment period. They were fed on corn silage, coast-cross hay, mineral salt ${ }^{2}$ and commercial ration ${ }^{3}$. Fifteen

\footnotetext{
${ }^{1}$ Ivotan Plus Pasta - Akzo Novel/Intervet - São Paulo Brazil.

${ }^{2}$ Agromix Eqüinos - Agromix Ltda. - Jaboticabal - Brazil.
}

days before infection (DBI), the animals were closely observed for clinical signs and blood samples were collected at fortnightly intervals for hematological, parasitological, and biochemical analyses. Neither trypanosomes nor anti- $T$. evansi antibodies were found in blood samples.

The used strain of $T$. evansi was originally isolated from a naturally infected $\operatorname{dog}$ by Machado and Moreira (1985). The cryopreserved strain was passaged in Wistar rats to allow trypanosome multiplication. Three donkeys (1, 2 and 3) were challenged via the jugular vein with $10 \mathrm{ml}$ of standardized inoculum, each animal receiving $1.0 \times 10^{5}$ trypanosomes. The control group consisted of two animals (4 and 5). The presence and degree of parasitemia was determined by examining wet blood films. The parasites were then counted in 500 microscope fields at 1,000 $\mathrm{x}$ magnification in blood smears stained with May-Gruenwald-Giemsa.

Blood samples were obtained daily by jugular vein puncture from $15 \mathrm{DBI}$ to 14 days post infection (DPI) and after this period, weekly up to 145 DPI. Blood samples for hematology were collected into tubes containing ethylenediaminetetraacetic acid (EDTA) as the anticoagulant. For plasma glucose assays blood samples were collected in tubes containing sodium fluoride, and for biochemical analyses they were collected into tubes containing no anticoagulant.

The packed cell volume (PCV) was measured using the standard microhematocrit method ${ }^{4}$ according to Schalm et al. (1975). The total red blood cell count (RBC), total white blood cell count (WBC) and hemoglobin ( $\mathrm{Hb})$ concentration were provided by an automated blood cell counter ${ }^{5}$ connected to a hemoglobinometer. Red cell indexes such as the mean corpuscular volume (MCV) and mean corpuscular hemoglobin concentration (MCHC) were calculated from the results obtained from $\mathrm{RBC}, \mathrm{Hb}$ and $\mathrm{PCV}$ according to Wintrobe (1942). The differential leukocyte count was

\footnotetext{
${ }^{3}$ Purina Eqüinos Passeio - Purina Alimentos S. A. - Paulínia - Brazil.

${ }^{4}$ Centimicro mod. 211 - FANEM - São Paulo - Brazil.

${ }^{5}$ CC-510 - CELM - São Paulo - Brazil.
} 
performed on blood smears stained with MayGruenwald-Giemsa.

The serum values for plasma glucose, protein and albumin were measured by enzymatic colorimetric methods using commercial kits ${ }^{6}$ according to established techniques (Ferreira Neto et al., 1981). Icterus index was determinated by the method of Meulengracht, as described by Coelho (1968). The globulin values were obtained from the difference between serum total protein and serum albumin concentration.

Animals were sedated with acepromazin $1 \%{ }^{7}$, at $0.1 \mathrm{mg} / \mathrm{kg}$, and after 10 minutes, by guaifenesin ${ }^{8}$, at $100 \mathrm{mg} / \mathrm{kg}$, followed by a barbituric general anesthesia with thiopental ${ }^{9}$ at $15 \mathrm{mg} / \mathrm{kg}$ and euthanized as indicated by Thurmon (1991), at different times, depending upon the presentation of individual symptoms for pathological examination. Donkeys 1, 3, 4 and 5 were euthanized at 136 DPI and animal 2 at 145 DPI. Macroscopic changes were evaluated at necropsy. Microscopic changes were determined by histopathology of HE stained sections.

The mean values obtained for hemograms and biochemical assays from infected and control animals were compared using the Tukey-test $(\mathrm{P}<005)$

\section{RESULTS}

Parasites were detected starting at 5 DPI by wet blood films and blood smears. Mean parasitemia peaks were observed between 5 and 98 DPI, and after 14 DPI, periods of low parasitemia were observed (Fig. 1), except at 42 and 49 DPI, where the mean parasitemia was 220 and 116 parasites/500 microscope fields. After 98 DPI, no parasites could be detected in the blood. Individual non-parasitemic periods were observed in each infected donkey between 21 and 98 DPI (data not shown) Control donkeys remained non-parasitemic throughout the experimental period.

A significant decrease in $\mathrm{RBC}, \mathrm{Hb}$, and $\mathrm{PCV}$ values of the infected animals was observed (Fig. 2). Red blood cell indices indicated anemia in all infected donkeys. The onset of anemia was observed after successive peaks of parasitemia by day, and the presented anemia - normocytic normochromic - was observed after successive daily peaks of parasitemia. No differences between infected and control animals for $\mathrm{MCHC}$, $\mathrm{MCV}$ and WBC were found.

Serum albumin concentration decreased gradually concomitantly to an increase in globulin levels in infected animals (Fig. 3), but no significant differences were detected in total protein mean values for both groups. Plasma glucose showed a significant decrease in infected animals between 28 and 70, at 98 and, from 119 to 145 DPI. Icterus index showed a significant increase in infected animals in variable periods. The highest icterus index was found at 145 DPI.

At necropsy, all infected donkeys showed splenomegaly with a relative increase of the white pulp, enlargement of mediastinal lymph nodes and lung congestion. Other significant lesions found in infected animals 1 and 3 were ischemic kidneys and congested liver. Microscopically, infected animals presented hemosiderosis and lymphoid hyperplasia in the lymph nodes and spleen, and chronic interstitial nephritis. The main histopathological features consisted of mononuclear infiltrations and cuffings in central nervous system (Fig. 4) and spinal cord. Mononuclear infiltrations were also observed diffused or in layers next the meninges and choroid plexus. Demyelination in some areas of cerebellum pediculus and neuropil vacuolization were observed (Fig. 5).

\footnotetext{
${ }^{6}$ Lab-Test - Belo Horizonte - BraziI.

${ }^{7}$ Acepran 1 \% - Univet S. A. - São Paulo - Brazil.

${ }^{8}$ Guaifenesin - Henrifarma Ltda. - São Paulo - Brazil.

9 Thionembutal - Abbott Laboratories North Chicago Chicago - USA.
} 


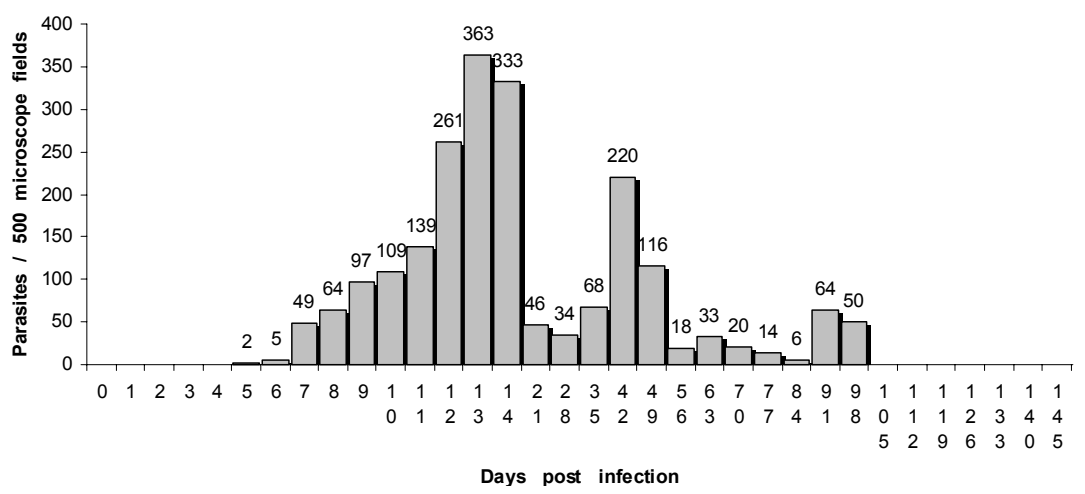

Figure 1. Mean parasitemia from infected donkeys with T. evansi during the infection period

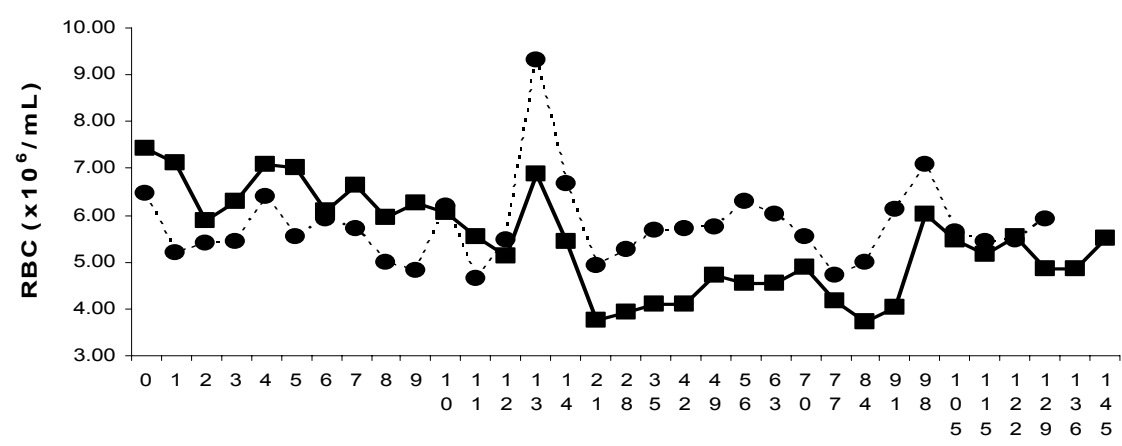

Days post infection
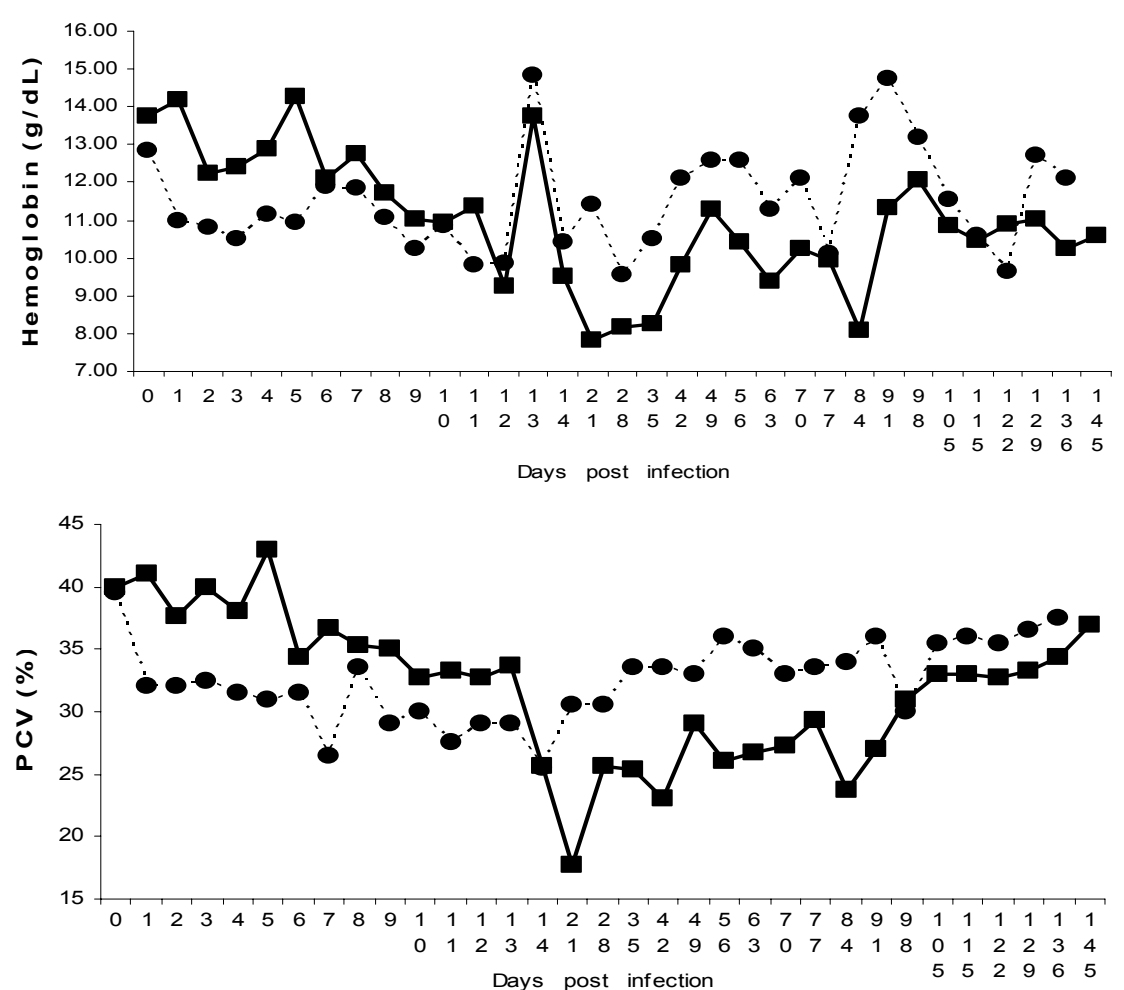

Figure 2. Values of red blood cells (RBC), hemoglobin ( $\mathrm{Hb})$ and packed cell volume (PCV) in donkeys

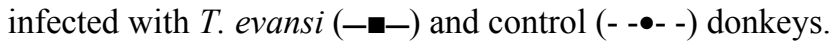



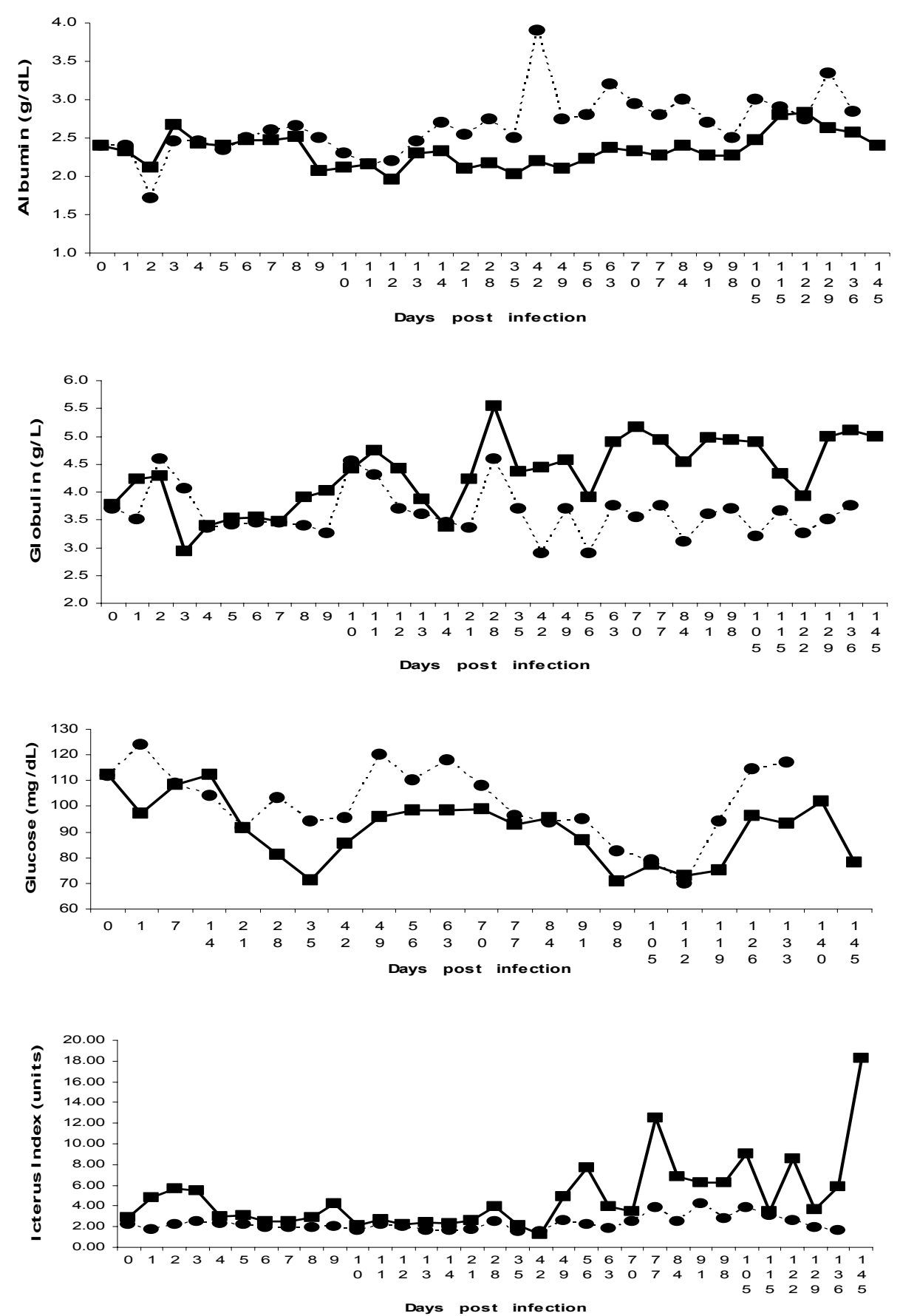

Figure 3. Values of serum albumin, globulin, plasma glucose and icterus index in donkeys infected with T. evansi (--) and control (- -๑- ) donkeys. 


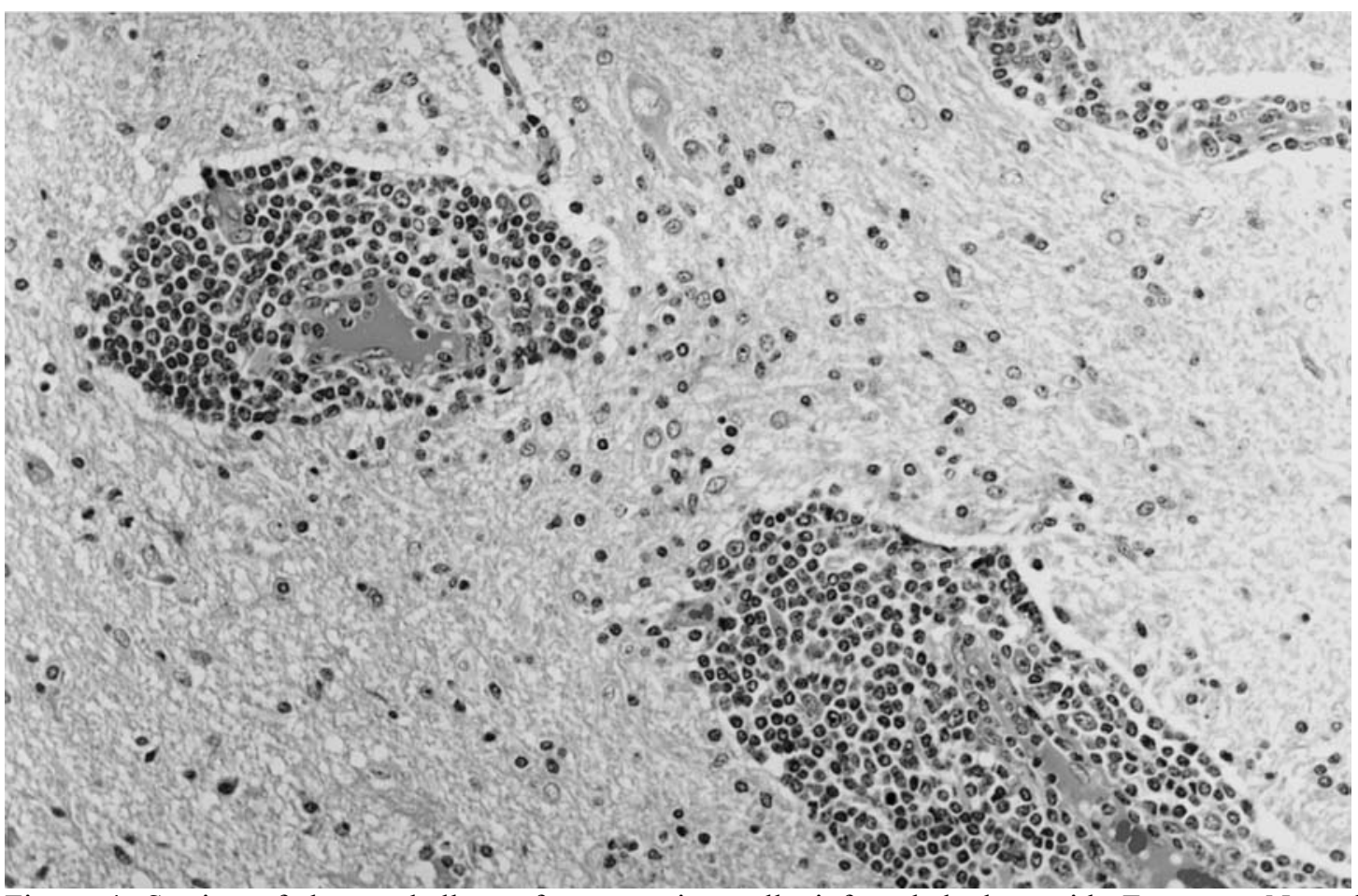

Figure 4. Section of the cerebellum of an experimentally infected donkey with $T$. evansi. Note the mononuclear infiltrations and mononuclear cuffings. (HE, 20x)

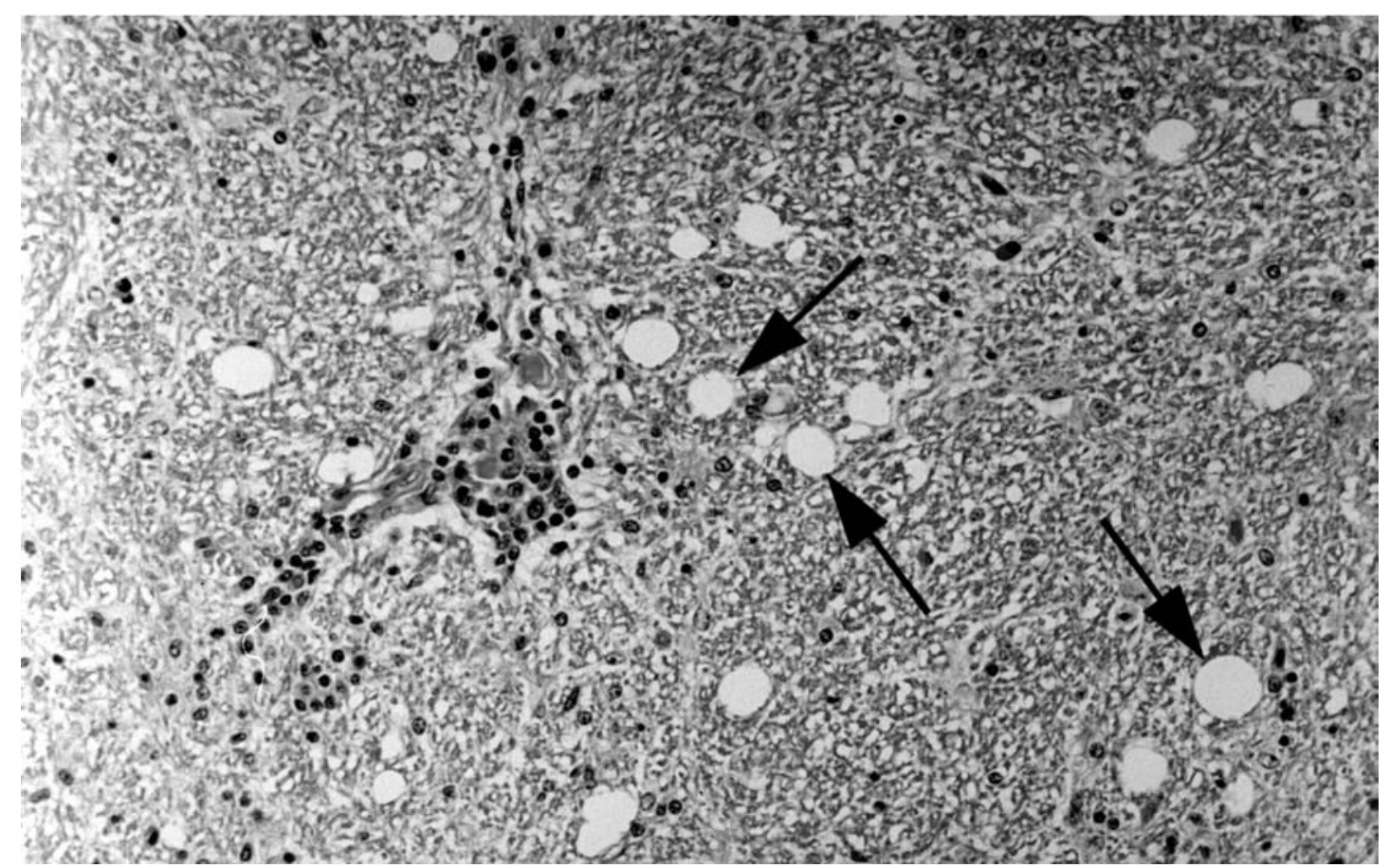

Figure 5. Section of the brainstem of a T. evansi experimentally infected donkey. Note the Neuropil vacuolization (arrows) and mononuclear infiltrations. (HE, 20×) 


\section{DISCUSSION}

The course of trypanosomiasis due to $T$. evansi in donkeys can be divided into two stages. The acute stage is characterized by high levels of parasitemia and development of anemia (Marques et al., 2000), characteristics observed until 14 DPI in this study, as also obtained by Aquino et al. (2002) and Herrera et al. (2002). Despite being a significant feature of the disease, the origin of the anemia in trypanosomiasis is not completely elucidated. Evidence suggests that its etiology is multifactorial and hemolysis, hemodilution and disorder and/or noncompensatory erythropoiesis are some of the mechanisms proposed (Jenkins and Facer, 1985). Increases in icterus index occurs concomitantly with parasitemia periods in horses (Marques et al., 2000), and it indicates hemolysis. However, icterus index increased during the first three days and at 9 DPI, when the first parasitemic peaks were seen, suggesting that massive hemolysis can not be an important factor for the development of anemia in donkeys in the acute stage.

In the chronic stage of the infection, from 21 DPI, only a few or no parasites could be found in the blood, differently of Soodan et al. (1996) observations in donkeys, where trypanosomes were seen during all experimental period. Donkeys infected with the Brazilian strain of $T$. evansi survived up to 145 days, in contrast to only 42 days of survival with an Indian strain (Soodan et al., 1996). The Brazilian strain may play an important role in the occurrence of trypanosomasis of horses in Brazilian Pantanal, considering the longer survival and the long-term exposure of herds to its vectors (Tabanidae).

In the chronic stage of the disease, most of visceral organs appeared normal at postmortem gross examinations. According to Tizard (1998), diseases caused by trypanosomes induce the formation of high levels of systemic antigenantibody immune complexes and their consequent deposition in the heart, liver, brain and kidneys, may possibly play a role in tissue damage. However, some reports indicated that trypanosomes can cause tissue inflammation directly as a result of the infection (Losos, 1986; Sudarto et al., 1990; Damayanti, 1993). A gradual decline in serum albumin in the infected donkeys, during the course of infection, suggested hepatic damage, while the increase in globulin levels might have been due to enhanced antibody production. Hyperglobulinemia coupled with by hypoalbuminemia in the infected donkeys is similar to observations found in other mammal hosts parasited by $T$. evansi (Singh et al., 1988; Monzon and Villavicencio, 1990; Soodan et al., 1996). According to KatungukaRwakishava et al. (1992), decreased serum albumin levels observed in salivarian trypanosome infections may be due to hemodilution. Hypoglycemia has been reported in infected animals (Katunguka-Rwakishava et al.,1992; Silva et al., 1997) and can occur due to the increase of the metabolic rate caused by fever (Stephen, 1986), hepatocyte degeneration (Von Brand, 1973) or glucose consumption by the trypanosomes (Opperdoes et al., 1987). Increases of icterus index from 49 DPI could be caused by increases of antibody levels, what indicates that immunomediated hemolysis may be an important factor at chronic stages in donkeys.

Meningoencephalitis as observed in the infected donkeys has also been reported in infected dogs (Aquino et al., 2002), coatis (Herrera et al., 2002), African free-living ruminants parasited by salivary gland trypanosomes (Losos and Gwamaca, 1973), donkeys (Soodan et al., 1996) and horses (Marques et al., 2000). The observed lymph nodes and spleen with follicular hyperplasia might be indicative of an immunological response by the infected donkeys. Pulmonary congestion and chronic interstitial nephritis developed by infected animals may be due to immune complex deposition and complement cascade reaction (Tizard, 1998).

This study showed that donkeys experimentally infected with a Brazilian strain of $T$. evansi developed a chronic form of disease, which is associated with anemia, meningoencephalitis, follicular hyperplasia of lymph nodes and spleen and low values of serum albumin and plasmatic glucose.

\section{ACKNOWLEDGEMENTS}

We thank to Rosangela Yamasaki de Andrade and Francisca de Assis Ardisson for technical assistance. 


\section{REFERENCES}

AQUINO, L.P.C.T.; MACHADO, R.Z., ALESSI, A.C. et al. Hematological, biochemical and anatomopathological aspects of experimental infection with Trypanosoma evansi in dogs. Arq. Bras. Med. Vet. Zootec., v.54, p. 255260, 2002.

COELHO, L. L. Técnicas de laboratório clínico. 3ed. Rio de Janeiro: Atheneu, 1968. p.98-101.

DAMAYANTI, R. Identification of Trypanosoma evansi in infected rat tissues by immunohistochemical methods. Penyakit Hewan, v.25, p.11-13, 1993.

FERREIRA NETO, J.M.; VIANA, E.S., MAGALHÃES, L.M. Patologia clinica veterinária. Belo Horizonte: Rabelo, 1981.279p

FRANKE， C.R.; GREINER， M.; MEHLITZ， D. Investigations on naturally Trypanosoma evansi infections in horses, cattle, dogs and capybaras (Hidrochaeris hidrochaeris) in Pantanal of the Poconé (Mato Grosso, Brazil). Acta Trop., v.58, p.159-169, 1994.

HERRERA, H.M.; AQUINO, L.P.C.T.; MENEZES, R.F. et al. Trypanosoma evansi experimental infection in the South American coati (Nasua nasua): hematological, biochemical and histopatological changes. Acta Trop. v.81, p.203-210, 2002.

JENKINS, G. C.; FACER, C. A. Hematology of African trypanosomiasis. In: TIZARD, I. (Ed).Immunology and pathogenesis of trypanosomiasis. Boca Raton: CRC, 1985. p.13-44.

KATUNGUKA-RWAKISHAVA， E.; MURRAY， M.; HOLMES, P.H. The pathophisiology of ovine trypanosomiasis: haematological and blood biochemical changes. Vet. Parasitol., v.68, p.231-225, 1992.

LOSOS, G.J. Infectious tropical diseases of domestic animals. Essex: Longhman Scientific \& Technical, 1986. p. $183-254$.

LOSOS, G.J.; GWAMACA, G. Histological examination of wild animals naturally infected with pathogenic African trypanosomes. Acta Trop.; v.30, p.1-2, 1973.

MARQUES, L. C.; MACHADO, R.Z.; ALESSI, A.C. et al. Experimental infection with Trypanosoma evansi in horses: clinical and haematological observations. Rev. Bras. Parasitol.Vet, v.9. p.11-15, 2000.

MACHADO, R.Z.; MOREIRA, R.D. Identificação e isolamento de Trypanosoma evansi em um cão do município de Camapuã, MS. In: ENCONTRO DE PESQUISAS VETERINÁRIAS, 10., 1985, Jaboticabal. Anais... Jaboticabal: 1985. p.66.

MONZON, C.M.; VILLAVICENCIO, V. Serum proteins in guinea pigs and horses infected with Tripanosoma evansi (Steel, 1885). Vet. Parasitol.; v.36, p.295-315, 1990.
OPPERDOES, F.R.; COPPPENS, I.; BAUDHUIN, P. Digestive enzymes, receptor-mediated endocytosis and their role in the nutrition of the bloodstream-form trypanosome. In: CHANG, K.P., SNARY, D. (Eds). Host-parasite cellular and molecular interactions in protozoal infections. Berlin: Springer-Verlag, 1987. p.5165.

RAMIREZ, L.E.; WELLS, E.A.; BETANCOURT, A. $L a$ tripanosomiases en los animales domesticos en Colombia .[s.l.]: Centro Internacional. Agricultura. Tropical, 1979. $71 \mathrm{p}$.

SCHALM, O.W.; JAIN, N. C.; CARROL, E. J. Veterinary hematology. 3.ed. Philadelphia: Lea \& Febiger, 1975. 807p.

SILVA, R.A.M.S. HERRERA, H.M.; BARROS, A.T.M. Trypanosomosis outbreak due to Trypanosoma evansi in the Pantanal, Brazil. A preliminary approach on risk factors. Rev. Elev. Med. Vet. Pays Trop., v.48, p.315-319, 1995.

SILVA, R.A.M.S.; VICTÓRIO, A.M.; RAMIREZ, L. et al. Effects of Trypanosoma evansi on the blood chemistry and hematology of coatis (Nasua nasua) naturally infected in the Pantanal, Brazil. Mem. Inst. Oswaldo Cruz., v.92, supl. 1, p.110, 1997.

SINGH, V.; RAISINGHANI, P.M.; SHEKHAWAT, V.S. Blood glucose and serum protein levels in experimental Trypanosoma evansi infection in buffalo calves (Bubalus bubalis). Indian Vet. Med. J., v. 12, p. 233-238, 1988

SOODAN, J. S.; SOOD, N. K.; KHAHRA, S. S. et al. Clinic-pathological studies in donkeys experimentally infected with Trypanosoma evansi. Indian J. Anim. Sci., v.66, p.443-448, 1996.

STEPHEN, L.E. Trypanosomiasis: a veterinary perspective. Oxford: Pergamon, 1986. 511p.

SUDARTO, M.W.; TABEL, H.; HAINES, D.M. Immunohistochemical demonstration of Trypanosoma evansi in tissues of experimentally infected rats and a naturally infected water buffalo (Bubalus bubalis). $J$. Parasitol., v.76, p.162-167, 1990.

THURMON, J.C. Euthanasia. In: MUIR, W.W.; HUBBELL, J.A.E. Equine anesthesia. St Louis: Mosby, 1991. p.485-495.

TIZARD, I.R. Imunologia veterinária: uma introdução. 5ed São Paulo: Roca, 1998. p.331-332.

VON BRAND, T. Biochemistry of parasites. 2ed New York: Academic, 1973. 409p.

WINTROBE, M.M. The size and hemoglobin content of the erythrocyte, methods of determination and clinical application. J. Lab. Clin. Med., v.17, p.899-901, 1942.

WOO, P.T. Salivarian trypanosomes producing disease in livestock outside of sub-Saharan Africa. In: KREIER, J.P. Parasitic protozoa. New York: Academic, 1977. v.1, p.270-295. 